\title{
Walking Softly in the Bush: Apprenticing to the Earth in an Ecological Curriculum
}

\author{
Jodi Latremouille \\ Thompson Rivers University \& Vancouver Island University \\ \& Vern Latremouille \\ Independent Scholar
}

\begin{abstract}
:
In this piece, we conceptualize walking in the Bush as an act of ecological apprenticing. Even after many years of learning/teaching, we also attune to the limits of our knowledge, seeing ourselves as continually evolving in our practice of nurturing more ethical and responsible apprenticeship relations, both out in the Bush and in the classroom. Together, we write about places in the Bush that are sacred to us, places around the Nicola Valley and the Nehalliston in the interior of British Columbia. We undertake a holistic and relational dialogue, grounded in life writing and literary métissage (Erika Hasebe-Ludt, Cynthia Chambers \& Carl Leggo, 2009). We interpret the work of an ecological curriculum through four interrelated concepts of apprenticing: 1 ) as a sustained and lifelong, imperfect and unfinished practice; 2 ) as learning/teaching through sensory heartful attunement; 3 ) as teaching/learning through wonder; and 4) as a gift which creates relationships and obligations. Drawing on Vern's lifelong pedagogical work of "walking in the Bush" and Jodi's poem entitled "Huckleberry Prayer," we undertake an intergenerational dialogue around an ecological curriculum as an act of apprenticing to the Earth.
\end{abstract}

Keywords: ecological curriculum; life writing; literary métissage 


\section{Marcher doucement dans les bois : apprendre à la terre dans un programme écologique}

\section{Résumé :}

Dans cette pièce, nous conceptualisons la marche dans les Bois comme un acte d'apprentissage écologique. Même après de nombreuses années d'apprentissage/d'enseignement, nous nous adaptons également aux limites de nos connaissances, nous voyant évoluer continuellement dans notre pratique d'entretenir des relations d'apprentissage plus éthiques et responsables, à la fois en Brousse et en classe. Ensemble, nous écrivons au sujet de lieux dans les Bois qui nous sont sacrés, des lieux, des endroits autour de la vallée de Nicola et du Nehalliston à l'intérieur de la Colombie-Britannique. Nous entreprenons un dialogue holistique et relationnel, fondé sur l'écriture de la vie et le métissage littéraire (Erika Hasebe-Ludt, Cynthia Chambers \& Carl Leggo, 2009). Nous interprétons l'oeuvre d'un programme écologique à travers quatre concepts interdépendants de l'apprentissage : 1) comme une pratique soutenue et permanente, imparfaite et inachevée; 2) comme l'apprentissage/l'enseignement par l'harmonisation sensorielle du cœur; 3) comme l'enseignement/l'apprentissage par l'émerveillement; et 4) comme un cadeau qui crée des relations et des obligations. En nous inspirant du travail pédagogique de Vern de «marcher dans les Bois » et du poème de Jodi qui s'intitule « Huckleberry Prayer », nous entreprenons un dialogue intergénérationnel autour d'un programme écologique comme acte d'apprentissage de la Terre.

Mots clés : le curriculum écologique; l'écriture de la vie; le métissage littéraire 


\section{Some Introductions: Acts of Apprenticing in an Ecological Curriculum}

odi: When I follow my father out into the Bush, I apprentice to his ways of moving along
pathways, of paying attention and speaking; I do my best to follow in his footsteps and
mimic his own apprenticing to the Earth — to the topographies, to the voices and signs, and to the relatives who live there with us. My father walks softly in the Bush. He respects the Beings that live there. He has spent years walking in their trails, tracking their scents and their calls, and learning their habits and their preferences. He gives thanks for the lives he takes that sustain him and his family, and he takes only what he needs. He attends to human people, too, taking the time to listen to their stories, with all his heart.

Vern: My father, Louis Latremouille, took a job in forestry in the Nicola Valley, moving our family here when I was quite young. Aside from a few stints in Rimbey, Alberta and a fishing camp in Little Fort, British Columbia, I have always been drawn back to this Nicola Valley. It's the feel of the place. It provides everything I need, physically, psychologically and spiritually. Even Little Fort, where I was raised till 12 years old and where my father lived the first 50 years of his life, could not draw me back. Although the fishing camp he started and that we ran for many years does tug at my heartstrings occasionally. I guess that's what they call roots.

Jodi: Having grown up on a hobby farm on Fox Farm Road on Iron Mountain overlooking Merritt, BC and the Nicola Valley, I am only in recent years coming to appreciate the power of this sacred place. The Nicola Valley is the place of the Scw'exmx of the Nlaka'pamux peoples, as well as the Sylix (the people of the Okanagan territories). Growing up, I did not know the land I lived on, nor the Indigenous nations who welcomed me as a guest here. I had friends and family members whom I dearly loved, but I never really understood who we were in relation to each other, in these places we shared. As a Kid, I would charge out in the Bush, building forts, chasing animals and cutting Logs, without thinking too much about whom or what I was trampling on. Although my parents, Vern and Lorna Latremouille, spent many years sharing their knowledge, respect and love for this place, I look back and wonder why I wasn't listening closely enough in those days. I am trying to listen more closely now.

As we walk softly, we apprentice to the Earth; we "bind by legal agreement" (Old French verb aprentiz, Online Etymology Dictionary, n.d.), in reciprocal obligation to that which nourishes and gifts us with life. The related French word apprendre - which means, simultaneously, "to learn" and "to teach" (ibid) reminds us to attune with wonder to the ecological ways of living, loving and giving back to the Earth. And now, even after many years of this simultaneous practice of learning and teaching, we also attune to the limits of our knowledge, seeing ourselves as profoundly "unskilled, inexperienced" (ibid) in our evolving practice of nurturing more ethical and responsible apprenticeship relations, both out in the Bush and in the classroom. We consider curriculum as a conversation freely given and received in relation with the entire world, including our human relations, all of the beings we share this Land with, and the earthly and cosmic elements. 
Michael Derby (2015) describes this as an education of "storytelling: where chatter, laughter, conversations, stories, songs, and dreams are as continuous as breathing" (p. 14).

In what follows, we share stories of places in the Bush that are sacred to us, places around the Nicola Valley and the Nehalliston in the interior of British Columbia. In this holistic and relational dialogue, grounded in life writing and literary métissage (Erika Hasebe-Ludt, Cynthia Chambers \& Carl Leggo, 2009), ${ }^{1}$ we try to pay attention to our places, and to understand who we are, in braided, responsible relation with each other and all of the world. This interwoven and juxtaposed text full of points of accord and dissonance is, we hope, "stronger and more complex than any of our individual stories" (p. 7). We interpret the work of an ecological curriculum through four interrelated concepts of apprenticing: 1) as a sustained and lifelong, imperfect and unfinished ("unskilled," "inexperienced") practice; 2) as learning/teaching through sensory, heartful attunement; 3) as teaching/learning through wonder (French, apprendre: simultaneously "to learn," and "to teach"); and 4) as a gift that creates relationships and obligations ("bound by legal agreement"). Vern shares stories from his lifelong pedagogical work of "walking in the Bush," while Jodi reflects on her experiences of apprenticing, through narration and through a poem, offered in parts, entitled "Huckleberry Prayer". We seek to write and "read [our lives] and living in creative and critical ways that open up possibilities for living well" (Carl Leggo, 2019, p. 144). We share stories spanning many generations of ancestors and descendants-from Vern's parents and Veteran Trees, down to Jodi's children, fields of Fireweed, and the baby Grouse chicks that were never born-to undertake an intergenerational dialogue regarding what it might mean to apprentice to the Earth in an ecological curriculum.

Jodi: When I follow my father out into the Bush, I apprentice to his attuned ways of moving along pathways, of paying attention and speaking. I do my best to follow in his footsteps and mimic his own apprenticing to the Earth-to the topographies, to the voices and signs, and to the relatives we enter into relationship with there. I don't always get told what to do; I'm expected to watch and listen closely. Stay close, but don't stumble or step out of line. Don't ask too many questions too soon or too loudly. If I am careful, and patient, I might get to chop some wood into kindling on my own, or tie a fly onto the fishing line, or drive the last stretch out to the Berry picking spot. I still feel his eyes burning into my back and his breath held tight to his chest while I maneuver the last corner on the switchback. I still need to practice. I look, listen, and pay attention to what he is looking at. The answers will rarely be in the language I am fluent in, so I take notes or repeat a mantra to remember. I go back to the roadmap, review the text, read, sit, study, forget. I go back and visit again. He is still there, waiting.

Vern: Sometimes I think I was a Cougar in a former life. I am drawn to the mystery of a Buck allowing himself to be seen at the edge of a clearing—or better yet, the thrill of catching him in his

\footnotetext{
${ }^{1}$ Please note, in all APA citations, the first names and last names are intentionally used, and papers with multiple authors include the full names of all authors. We have also capitalized the names of our more-than-human relations and teachers in our own writing. This is intended to live up to the intimate, relational and gifted nature of an ecological curriculum, and the responsibility we feel to properly name and give credit to our sources of inspiration.
} 
bed for a quick, clean kill. Actually, this is quite unlike a Cougar; nothing too quick or clean there, if the signs I have read around a Cougar kill are any indication.

A day in the Bush from daylight till dark, walking the trails of the game I seek, always studying the signs they leave, always learning, getting to know them better and better. My respect and connection with them grows. I sit at my lunch Fire in a snowy world and contemplate how I would get them without the advantage of a rifle. I still feel inadequate. I would not last a winter with the skills I have now; they would have to be honed by one who knows. One who has walked this trail before me. I am humbled.

I enjoy eating the meat I obtain. It sustains me and my family. The plants they eat are converted into what nourishes us best, and I am grateful.

\section{Jodi: Huckleberry Prayer-Prelude}

A brief conversation on a Sunday afternoon in late August.

Vern: We're heading out Huckleberry picking this weekend, want to come?

Andy's Lake, you know, where we went last year.

Jodi: Are the Huckleberries pretty good?

Vern: Yah, pretty good. A little sparse in some spots,

but if you hit a patch, yah...

couple of days ago we got a gallon each in a few hours.

Not like that McGree Creek Year though!

Nothing compares to that year out at McGee Creek!

Jodi: Oh! I will never forget that!

We can't keep being disappointed when the picking doesn't live up to that year! We'll always be searching for the magical McGee Creek year.

The McGee Creek Year sets a certain standard.

A magical, true, real standard.

Jodi: Well, we'll cancel our weekend plans

we can come up and stay overnight in the camper.

We should talk about that article we are going to write together, while we're up there.

A good place to sit and chat.

I was thinking I could take some notes, do some writing, send it to you, see what you want to add, or we could just talk again... 


\section{Walking Softly in the Bush}

When the Berries are ripe,

you drop everything and pick.

When it's time, it's time.

Vern: All we'll need is a good bottle of scotch and a Campfire, we'll have that thing written in a night.

\section{Apprenticing as Practice: Hand Over Hand}

It's like making a path through the forest. At first it's rough going, with a lot of obstructions, but returning to it again and again, we clear the way. After a while the ground becomes firm and smooth from being walked on repeatedly. Then we have a good path for walking in the forest. (Ajahn Chah, 2005, p. 83)

Vern: When I was 12 years old, we returned from a successful hunting trip. My mother, Gertie, was waiting expectantly as we drove in. As we pulled five Deer from the Volkswagen station wagon, two of which I had shot with a borrowed rifle, my mother, who would sneak Salt into our pockets at breakfast hoping it would attract the Deer, clapped her hands and said, "The Salt worked!" With the winter's meat supply secured, and some to give to the neighbours, we could sell the Cows we raised to earn some much-needed money for other things. What a sense of pride and accomplishment that experience left me with.

I was never really taught how to hunt; when we went to the Bush, my father, my brother and I would each go our separate ways with a very tentative plan that was open for change. The only stipulation was being out by dark. Our safety training was "Don't point that rifle at anything you don't intend to kill." We only had to be told once, for there were consequences if we didn't obey. A march to the woodshed, the cutting of a good stout kindling Stick and several good whacks on the ass till the tears flowed. Only once can I remember this happening-that's all it took. The rest of our hunting education was watching our father, listening while he talked to other hunters, and practicing hunting the Squirrels and other animals near our farm.

\section{Jodi: Huckleberry Prayer}

My Dad tells a story.

When he was a little boy, not yet able to walk, he would get plunked down under a heavy Huckleberry Bush, left to eat to his heart's content.

While his three older siblings and parents would fill their buckets, maybe two, three times in a good day.

They had a lot of picking to do. 
He passed this prayer on to his babies, us-and on to our babies, too.

I lived through a major transition in Huckleberry picking world:

when I was younger, we used to use those sturdy ice-cream pails with the strong metal handles. We would cut a hole in the lid.

Now, those pails have flimsy plastic handles, not much use for packing ice cream, let alone our precious Berries.

Now, we take a well-washed, four-litre white plastic milk jug,

cut a hole opposite the handle.

Just big enough for a loose fist to

slip in,

drop

a handful

of Berries:

not big enough to lose a drop if a stumbling step is taken

over a fallen, loose-barked Log.

\section{Apprenticing as Learning/Teaching: Attuning through the Heart}

Intelligence exists in all of nature, not just the human mind, but throughout the entire human body, in the bodies of plants, animals alike, soil, water, sky. (Susan Griffin, 1995, p. 45)

Vern: A book I am attempting to understand, The Secret Teachings of Plants: The Intelligence of the Heart in the Direct Perception of Nature, (written by Stephen Harrod Buhner, and published in 2004), describes this heart connection all of us could have with all plants (see p. 147). Or is this heart connection just a matter of being able to tune in more carefully when I can get away from all civilized distractions? Is it about being in a place where I feel whole and at home? Where I can stop the grinding of my linear mind and let my heart and gut take over? In the words of Henry David Thoreau, "A man has not seen a thing who has not felt it" (as cited in Stephen Harrod Buhner's 2004 work, p. 147). I find it very exciting that these things I have felt since childhood have been experienced and described by others. I am no longer a weird loner who could spend most of my time alone in my wanderings, hunting, trapping and foraging.

I understand now that it is my gut and heart that are activated when I look up in awe at a towering old Veteran Tree, or give a spontaneous gasp when those extra-large, shiny black Huckleberries appear before me. I've read that the heart is the main organ for communication and perception. The mind's role is to analyse after the heart has chosen a path forward (Stephen Buhner, 2004). This challenges René Descartes' famous dictum, "I think therefore I am." A more accurate dictum would be, "I feel therefore I am."

During a personal development seminar that I participated in many years ago on the San Juan Islands, one task we were assigned was to have no communication with others for 24 hours. Late that night, I went for a walk on the Beach, and, as I listened to the Waves rolling in, I heard something- 


\section{Walking Softly in the Bush}

the Waves were speaking to me. I found tears rolling down my face as understanding flooded me. What is clear to me now is that my heart was activated in that moment as my primary mode of perception. The stronger, more aggressive Waves sent negative feelings through me; the gentler the Wave, the more joyful I felt. They were saying my way forward was to be gentler, more accepting, kinder.

This "humanizing" of non-human relations-as having their own feelings, consciousness, intelligence-is a recent phenomenon for me. As I get closer to the end of my life, I am choosing to ingest different philosophies, to be open to new ways to understand intelligence. I try to give credibility to others' beliefs, and I try to connect with what my heart and gut are telling me.

\section{Jodi: Huckleberry Prayer}

Up over by the Coquihalla Lakes, yah, just up above that old logging road over there past the turnoff there. Yah, we found a good patch, not too many know about it, not too picked over, not like those ones near the main road.

You're welcome to come with us next year, yup, we'll call ya in September when the picking's good.

We would come across other Berry-picking folks out in the mountains.

We knew about their comfortable, low-lying camps.

We'd drive by, wave and chat out the truck window, friendly-like, and they'd wonder...

They knew we had an ambitious secret, but they also knew our secret was at the top of a jaw-dropping,

breath-taking,

put-the-hubs-in-don't-look down-30-km-switchback-logging-road.

That one year we got an ATV-now we could go even further!

Even straighter!

Up the Mountainside.

Sometimes, rumble-rattling up in the back of the pick-up, contemplating

just exactly how good of a driver my father was, I wondered

why we couldn't just be content and comfortable down there, too.

Walking up the high alpine road, checking Berries along the way.

Sitting in the back of the truck bed while grandpa gets out to stomp off.

Comes back with the verdict.

Good, not great.

Move on. 


\section{Apprenticing as Teaching/Learning: Wondering Through Life}

The beginning of wisdom is the same as its attainment: wonder. The truest statement in the world is "you never know." There is always something to evoke wonder, to wonder about, because this world, this life, this universe, this reality is far more than the sum of its parts. Even the slightest detail contains much more. The overwhelming awe and wonder we feel teach us more than we can ever glean or come to know of things. In the presence of that wonder, the head has no answers and the heart has no questions. (Richard Wagamese, 2016, p. 99)

Vern: At a very young age, I was taught to be a contributor to the family. I would go to the clearings around our farm in Little Fort, BC, and pick wild Strawberries. Enough for Strawberry shortcake for the family of six, no small task as they were tiny little Berries. The praise and admiration that I received from the family for this contribution instilled in me a passion for picking Berries to this day.

I don't mind gathering my own plants. I recently received a new book, The Boreal Herbal: Wild Food and Medicine Plants of the North: A Guide to Harvesting, Preserving, and Preparing by Beverly Gray (published in 2011 by Aroma Borealis), which has educated me on many plants that I have seen often, yet largely ignored in the past. Many are not only edible, but can also be used medicinally.

I have taken to gathering Stinging Nettles as well. They make a very nice tea, for once they are dried, they will give up their stinging ways (Beverly Gray, 2011). On a recent ATV ride with two other couples, we stopped to pick Nettle, which they had never done. Ironically, this nourishing plant, along with Fireweed, Wild Raspberry and Thimbleberry, was growing prolifically on the edge of a pipeline transporting oil to the West coast. Chatting and laughing, we harvested the leaves with gloves to protect from the Nettles.

\section{Jodi: Huckleberry Prayer}

The Berry-picking jug is threaded through a belt-

for some of the older ones, it's a leather deal with a proper buckle

secured around the waist of weathered, weatherproof Bush pants,

nestled beside the well-sharpened Leatherman pocket-knife

smelling faintly of polished-off Fish guts and sausage;

for other, younger ones, a borrowed, improvised, scavenged, frayed rope affair nestled low on the hips over yoga pants or Nike shorts.

The very youngest ones pack the smallest Berry jugs,

tied over the shoulders with a piece of cord.

Sometimes they manage to cover the bottom of their jug

with a single layer of Berries.

Other times they give in to the tangy-sweet temptation. 


\section{Walking Softly in the Bush}

Silence and conversation.

Singing songs. Settling into the time.

Listening.

Making the trek back to the truck,

transferring the harvest into larger pails and coolers.

Grandma sees Bear poop!

Looks fresh, yikes, a big pile.

Full of seeds.

Where are the Kids?

We shift just a little closer, talk a little louder.

Call the Dogs, senses honed tight and sharp, poised

for a loud crack,

a warning huff,

a dark shape at the edge of the cutblock.

No, it's just a Bear-shaped Stump.

Settle back in to the prayer-picking rhythm.

Epic year-

McGee Creek!

Once in a lifetime.

Uncle hadn't been out to the Bush since that stroke, years ago.

He spent most of the day stuffing his mouth full of Berries.

Not even a single Berry to bring home to Auntie.

We scrounged up a handful for her to taste.

We dropped him off with his gifted Berries,

blue-lipped and grinning.

Thin year last year. Scoping out Fire patterns.

Ranging, walking, stretching our limits.

Berry calculations.

How many years after a Fire is the picking at its best?

How close to a Nurse Tree will the best Bushes grow?

How many weeks after the heavy Rains will the Berries last?

Another year, Grandparents camped out, picked 30 pounds-without usin three short days.

The phone-call celebration. The long-distance regret;

we had just moved away that summer.

We couldn't get back for picking that year. 


\section{Apprenticing as Gift: Binding Relations}

In the gift economy, gifts are not free. The essence of the gift is that it creates a set of relationships. The currency of a gift economy is, at its root, reciprocity. (Robin Wall Kimmerer, 2013, p. 29)

\section{Sitting on a Stump (Vern)}

I seem to do my best thinking while sitting on a Stump, or a Rock, or a Log, or under a Tree on the ground. What am I drawn to? Is it the reduced electromagnetic frequency that allows my meditative state? Or is it the grounding and release of the positive ions which actually have a negative effect on my body, as Ben Greenfield, (2020, p. 154) describes? Or is it the solemn presence of the plants infusing me with their ancient wisdom? They were on this Planet long before us and have an essence that I think we have all felt, which can make us feel connected to the ones that have gone before. The most important thing is to be alone with only the birds, animals, insects and plants as company.

I can always find ways to walk more softly on our ground: drive less; use less Water; make sure what I do use is sustainable. I have always paid attention to the populations of the game I harvest. If the Grouse have a bad spring with high chick mortality, that is a year I will leave them alone, though I love to eat them. When I don't see many Moose, I forego a hunting tag that year.

My heart is full when I think of my daughters Jodi and Sarah. They have turned out to be productive members of society with dreams and goals to be proud of.

Jodi has achieved a PhD, the first ever in our family! Education will be forever changed once she puts her stamp on it.

Henry David Thoreau asks, "What does education often do? It makes a straight-cut ditch of a free, meandering brook" (as cited in Stephen Harrod Buhner, 2004, p. 120).

Jodi's educational dream-stream will restore the channel to its ancestral bed.

Sarah has faced tremendous adversity and proven to be a strong and beautiful person. She leads with her heart.

I learn from them both. They help me understand what gestalt means in relation to the family. The whole is greater than the sum of the parts. We are bound to keep moving the gift.

Jodi: Huckleberry Prayer

Sometimes the Cousins come.

Other times large groups.

Always at least three generations of pickers.

Everyone has a role.

Mamas cooking lunch.

Kids and their pails, 


\section{Walking Softly in the Bush}

Learning the ways.

Dads making Fires,

lifting little ones over windfallen Logs.

Dogs darting back and forth, checking in, sniffing out.

Chatty Kids or singing Grandmothers also doing their part.

Alerting the Bears to take a wider route.

Grandpa and Grandma very serious about providing for the family.

Clean picking,

fast picking,

hungry picking,

selective picking.

Debates over which is more productive.

Sort out Twigs.

No, don't sort.

Roam.

No, stay put.

Dreaming Berries.

One day, my Dreaming-Daughter-

she was little,

a little tired of picking

after a long, wet day of tromping around the bushy cutblock-

She let her imagination run wild with wishful thinking,

In the typically human-wild-Child way.

"Mama, what if I invented a Huckleberry picking machine?"

"What if I could sit in that machine

And it would strip all the Berries off in record time?"

"What if I sent a helicopter to pick up

the buckets and buckets and buckets of Berries?"

"I could just sell the Berries and make a million bajillion dollars!"

Dreaming-Daughter, look how beautiful these Berries.

Tiny this year. So much work.

But smell.

Taste.

See the purple stain

on your fingers, your lips, and cheeks.

Afternoon wears along. 
Some tired young pickers are tired of picking.

Hunkered down at the Fire. Drawing pictures in the Dust.

We're tired, they yell up the cutblock.

When are we going home? They call out to the Mountains.

The Elder-Picker reminds in a gruff voice: it's not your job to decide.

Look at your purple lips in the mirror.

Remember who is picking for whom here.

\section{Some Re-Introductions: Drawn Back Home}

If human consciousness can be rejoined not only with the human body but with the body of the earth ... even ... the most daily acts [will be infused] with an eros, a palpable love, that is also sacred. (Susan Griffin, 1995, p. 9)

Jodi: I was drawn away from my hometown by the excitement, entertainment and stimulation of bigger cities and adventures. Having forgotten some of the teachings of my younger years, I felt for a long time that my attachment to the land was tenuous and strained, nothing more than intellectual. I went for the occasional hike, I followed current events with a critical eye, and I dutifully bought organic groceries, but I didn't feel the draw homeward until I began my Master's degree in Calgary, $A B$, in 2013. It now feels strange and wonderful to me to look back and realize that what started out as a purely intellectual journey has brought me closer to my emotional, spiritual, physical and ecological roots. I am learning to allow myself to cry more freely; I speak more honestly about my love for the Earth; I try to stand up more for this place, for people, for what I believe is right. I try to follow what Dwayne Donald (2012) calls a "curriculum for renewal and survival" (p. i). Having moved back again to the Nicola Valley in 2016, I have committed to apprenticing to this place once again. I am a little bit old, but I feel young. I have children to care for. I have only just begun.

Vern: In my will, I have asked that some of my ashes be placed on Dunn Peak which overlooks the Nehalliston Plateau, where the fishing camp, my father's ashes and both my parents' graves reside. Dunn Peak holds a special place in my heart. Years ago, I set out with my wife, Lorna, our two daughters, Jodi and Sarah, my sister, Marie, her husband, Nathan, and their son, Mark, from Baldy Mountain lookout to conquer Dunn Peak for our first time. After the first night, we started for the summit, but sadly, Jodi twisted her ankle and wasn't able to carry on. Lorna stayed behind with her at the first night's campsite while the rest of us charged on. By midday, we had scrambled up talus slopes and through Rock tunnels and achieved the top. I had an adrenaline-charged moment while looking over the sheer precipice. I was hanging over the edge, looking down, when my young nephew Mark sneaked up behind me and swatted the last tenacious Mosquito which had landed on my back! My heart leaped as I felt the sudden pull of the abyss below!

Lorna and Jodi stayed at the camp all day, holed up in the tent for hours, occasionally racing out of the tent to grab a snack from the cooler or a plant to identify, while fighting Mosquitoes that were up-your-nose thick and that swarmed into the tent each time they unzipped the zipper. 


\section{Walking Softly in the Bush}

I hope the request in my will might give Jodi a chance to summit Dunn Peak once and for all. With all the family she can manage to drag along. And not by helicopter! I also hope my nephew, Mark, goes along, and, just when he is peeking over the edge of a precipice and his heart is rising in his chest, a Mosquito lands on his back.

Jodi: Huckleberry Prayer-Coda

This year, Dreaming Daughter, a little older now

picked a whole bucketful for the freezer.

Purple Berry feast-stains and all.

She said it was a good picking year-

not quite a McGee Creek Year,

but still, a pretty good year.

\section{About the Authors}

Jodi works in faculties of Education at Thompson Rivers University and Vancouver Island University. Her research interests include the following: hermeneutics; ecological, Indigenous and feminist pedagogy; social and environmental justice; life writing; and poetic inquiry. She loves gardening, playing the piano, tending to Bees, Chickens, children and other family members, and hiking in the Bush. Jodi.Latremouille@viu.ca / jlatremouille@tru.ca

Vern is a retired forestry worker. He has also worked as a cowboy, a fishing camp operator and a machine operator. He enjoys hunting, fishing, Mushroom and Berry picking, and he has a current interest in learning about local plants for health and the table. After curing his type 2 diabetes with diet alone, he has spent several years researching how our food and environment affect us. His greatest joy is spending time on the land with his family, in camaraderie around the Campfire. latlov@telus.net

\section{References}

Buhner, Stephen Harrod. (2004). The secret teachings of plants: The intelligence of the heart in the direct perception of nature. Inner Traditions.

Chah, Ajahn. (2005). Everything arises, everything falls away. Shambalah.

Derby, Michael. (2015). Place, being, resonance: A critical ecohermeneutic approach to education. Peter Lang.

Donald, Dwayne. (2012). Advance praise for a heart of wisdom. In Cynthia M. Chambers, Erika Hasebe-Ludt, Carl Leggo, \& Anita Sinner (Eds.), A heart of wisdom: Life writing as empathetic inquiry (p. i). Peter Lang.

Gray, Beverly. (2011). The boreal herbal: Wild food and medicine plants of the North: A guide to harvesting, preserving, and preparing. Aroma Borealis.

Greenfield, Ben. (2020). Boundless: Upgrade your brain, optimize your body \& defy aging. Victory Belt.

Griffin, Susan. (1995). The eros of everyday life: Essays on ecology, gender and society. Doubleday. 
Hasebe-Ludt, Erika, Chambers, Cynthia M., \& Leggo, Carl. (2009). Life writing and literary métissage as an ethos for our times. Peter Lang.

Leggo, Carl. (2019). Light and shadow: Four reasons for writing (and not writing) autobiographically. In Rita L. Irwin, Erika Hasebe-Ludt, \& Anita Sinner (Eds.), Storying the world: The contributions of Carl Leggo on language and poetry (p. 144-157). Routledge.

Online Etymology Dictionary (2020). Apprentice. Retrieved June 25, 2020, from https://www.etymonline.com/search?q=apprentice

Wagamese, Richard. (2016). Embers: One Ojibway's meditations. Douglas \& McIntyre.

Wall Kimmerer, Robin. (2013). Braiding sweetgrass: Indigenous wisdom, scientific knowledge, and the teachings of plants. Milkweed. 